\title{
REVIEW \\ Vegetation-based Wastewater Treatment Technologies for Rural Areas in Japan
}

\author{
Kaoru ABE ${ }^{1^{*}}$, Kunihiko KATO ${ }^{2}$ and Yasuo OZAKI ${ }^{3}$ \\ 1 National Institute for Agro-Environmental Sciences (Tsukuba, Ibaraki 305-8604, Japan) \\ 2 National Agricultural Research Center for Hokkaido Region, National Agriculture and Food \\ Research Organization (Sapporo, Hokkaido 062-8555, Japan) \\ 3 Akita Prefectural University (Akita, Akita 010-0195, Japan)
}

\begin{abstract}
Nitrogen and phosphorus loading of rural areas in Japan has recently exceeded environmental tolerance levels, thereby causing deterioration of aquatic environments. Rural areas need suitable low-energy, low-cost purification technologies. Vegetation-based water treatment uses the purification functions inherent to natural ecosystems and is therefore likely to be adaptable to rural areas. Here, we review the water purification processes associated with vegetation-based water treatment systems. We then describe three purification technologies that are being developed for practical water pollution treatment in rural districts. The first is a free-water-surface-flow constructed wetland planted with indigenous wild rice (Zizania latifolia) in the Koibuchi College biotope zone, which receives secondary-treated wastewater from the college dormitories. The second is a hybridtype subsurface-flow constructed wetland system for purifying milking-parlor wastewater in cold regions. The third is a biogeofilter channel in which terrestrial plants (including most crops) can be grown by adjusting the filter material height to suit the plants' moisture tolerance. We discuss the advantages and disadvantages of the three treatment technologies in terms of their introduction at various sites, and we consider yudone, a traditional vegetation-based purification system once used by Kyushu-region farmers.
\end{abstract}

Discipline: Agricultural environment

Additional key words: biogeofilter, constructed wetland, free water surface, garden type, hybrid

\section{Introduction}

In the past, the amounts of wastewater and solid waste arising from everyday living and agricultural production in rural areas were not very large, and a healthy water environment was maintained by natural purification and by making full cyclical use of these wastes in agricultural production. However, since rapid economic growth began, increased lifestyle diversification, increased mixing of residential and farming areas, more intensive agricultural production, and other factors have caused pollution loads in rural areas to exceed environmental tolerance levels, thereby worsening the water environment.

The dispersed nature of pollution sources in rural areas makes it difficult to apply the energy-intensive, large-scale water purification technologies used in urban areas. Rural areas need suitable low-energy, low-cost purification technologies.

Vegetation-based water treatment can remove organic matter, nitrogen, phosphorus, and other substances by using the purification functions with which natural ecosystems are endowed; it is therefore appropriate to rural areas ${ }^{15,23}$. This paper first presents an overview of various vegetation-based water treatment methods, then describes the purification technologies that are being developed for practical use in treating water pollution generated in rural districts. Finally, we discuss the advantages and disadvantages of the three treatment technologies in terms of their introduction at various sites, and we consider yudone, a traditional vegetation-based purification system once used by Kyushu-region farmers.

*Corresponding author: e-mail abekaoru@affrc.go.jp

Received 3 April 2009; accepted 24 November 2009. 


\section{Purification mechanisms in vegetation-based water treatment}

Vegetation-based water treatment removes organic matter, nutrient salts and other substances by treating wastewater with a combination of physical processing such as precipitation and filtering, chemical processing such as adsorption onto soil and other materials, and biological processing by plants and microorganisms $8,9,11,23$. Purification agents in the form of vegetation, filter beds (soil, etc.) and microorganisms contribute both directly and indirectly to water purification. Vegetation takes $\mathrm{N}$ and $\mathrm{P}$ from wastewater and calms waves, promoting the settling of suspended matter. Emergent plants supply oxygen to their rhizospheres via their aerenchyma, thereby supporting the growth of the aerobic microorganisms responsible for decomposition and nitrification. Selection of special materials to form the filter bed can improve the ability of the bed to adsorb ammonia and phosphorus. The filter bed also serves as habitat for microorganisms. Microorganisms decompose organic matter in the wastewater and promote nitrogen removal by nitrification-denitrification processes.

Vegetation-based water treatment systems offer some advantages:

1) Construction and maintenance are not expensive in terms of energy or cost.

2) Unlike activated sludge treatments and other methods, they excel at the removal of nutrient salts.

3) They can have valuable functions besides water purification; for example, providing habitats for a variety of organisms. They can be used as biotopes and for growing remedial vegetation in the form of agricultural, vegetable and floral crops.

However, they also have some disadvantages:

1) Their efficiency is lower than that of other methods such as activated sludge treatment, and the facilities require more space.

2) Treatment is easily affected by temperature, insolation and other environmental conditions, and the purification function is less stable.

3) Insufficient practical design and operation guidelines have been formulated and tested.

\section{Characteristics and main types of vegetation-based water treatment systems}

Research on the use of vegetation for wastewater treatment has a much shorter history than research on the activated sludge methods used in modern sewage treatment facilities. Constructed wetlands have been in the spotlight for only about 30 years in the West ${ }^{9,10,23,24}$, although their practical use is advanced in areas such as secondary and tertiary sewage treatment. The classification of vegetation-based systems is based primarily on the type of macrophytic growth and secondarily on the water flow regime ${ }^{23}$. Free-floating plants, free-watersurface-flow (FWS) systems with emergent plants and subsurface flow (underflow) constructed wetlands with horizontal subsurface flow (HSSF) or vertical subsurface flow (VSSF) are commonly used in constructed wetlands $^{23}$ (Fig. 1).

In Japan, wastewater treatment facilities that incorporate vegetation are often used for remediation of lakes, rivers and other water bodies ${ }^{19}$. There are also other types of facilities that cannot be classified among the constructed wetlands mentioned above ${ }^{15,19}$ (Fig. 1). The River and Watershed Research Institute in Tokyo has classified Japan's major vegetation-based water treatment facilities according to their characteristics (Table 1, Fig. 1). There are three main categories: pond with free-floating plants, wetland with emergent plants, and hydroponic. "Wetland with emergent plants" includes the two Western categories of FWS system and subsurface-flow constructed wetland. The hydroponic category is therefore newly created in this classification. Constructed wetland systems do not make large contributions to remediation by plant absorption of $\mathrm{N}$ and $\mathrm{P}$; $\mathrm{N}$ is removed mainly by the action of microorganisms, and $\mathrm{P}$ by adsorption onto soil and other materials. In the subsurface-flow constructed wetland described in the next section, the water surface is below the filter-bed surface; this system can therefore be used even in cold regions, because the water does not freeze ${ }^{12,13}$. This system is an example of improvements made to a European system to meet the needs of Hokkaido dairy farmers.

Hydroponic systems are better than wetland systems in terms of plant absorption of $\mathrm{N}$ and $\mathrm{P}$. A feature of the biogeofiltering method described in the next section is that it can use not only aquatic plants, but also profitable terrestrial crops such as vegetables and flowers $^{1-5}$.

\section{Use of vegetation-based water-treatment systems in rural areas}

As mentioned in the previous section, a disadvantage of vegetation-based water treatment systems is that the facilities require large amounts of space. However, in rural areas, greater amounts of space are available for 


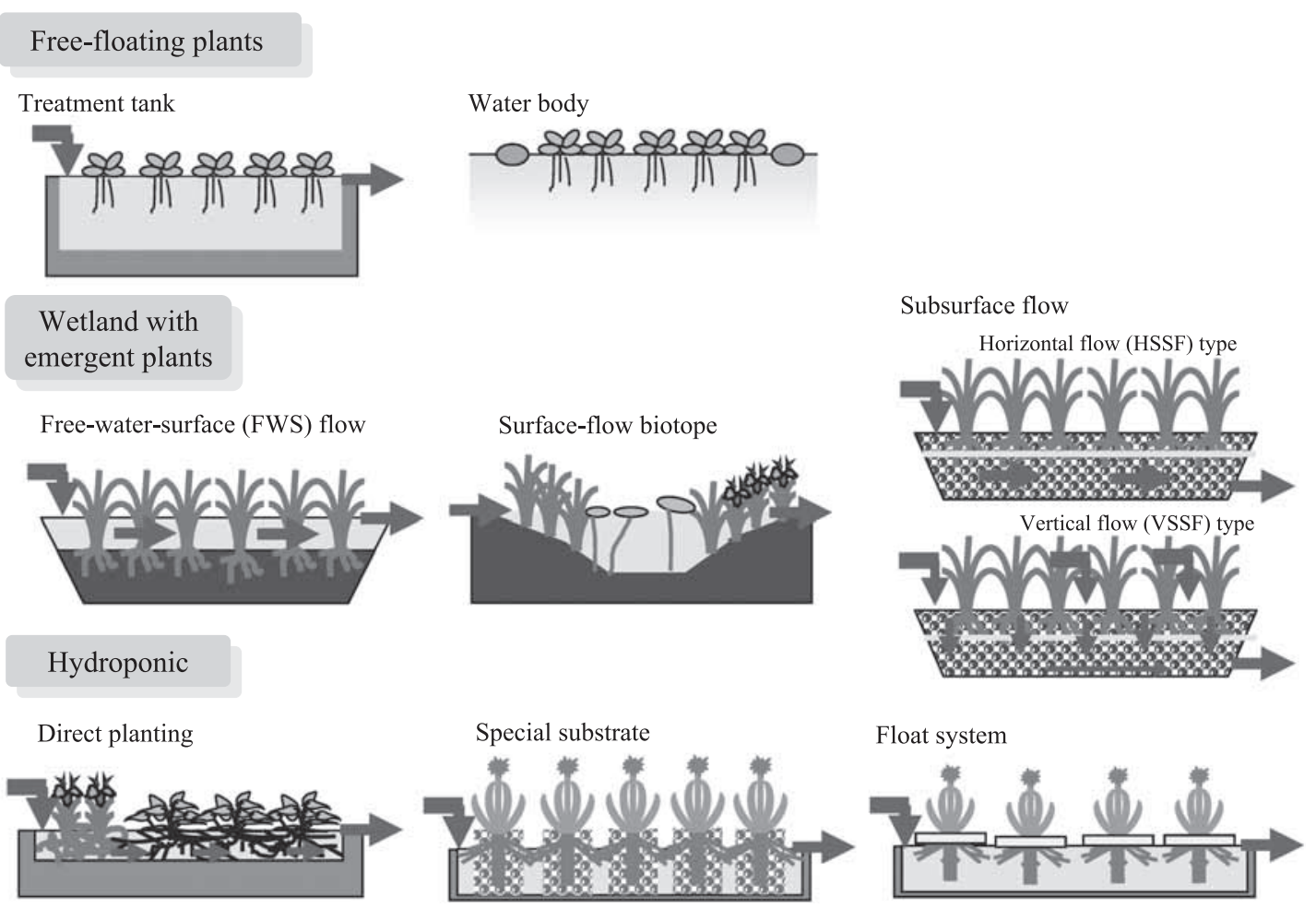

Fig. 1. Main types of vegetation-based water treatment facilities in Japan

Table 1. Classifications of vegetation-based water treatment technologies in Japan according to their main characteristics and concept

\begin{tabular}{|c|c|c|}
\hline Category & Subcategory & Characteristics and concept \\
\hline \multirow[t]{2}{*}{ Free-floating plants } & Treatment tank & $\begin{array}{l}\text { Tank with common water hyacinth (Eichhornia crassipes) and other free- } \\
\text { floating plants }\end{array}$ \\
\hline & Water body & $\begin{array}{l}\text { Part of a lake or river is partitioned off and common water hyacinth and other } \\
\text { free-floating plants are added. }\end{array}$ \\
\hline \multirow[t]{3}{*}{$\begin{array}{l}\text { Wetland with } \\
\text { emergent plants }\end{array}$} & $\begin{array}{l}\text { Free-water-surface } \\
\text { flow (FWS) }\end{array}$ & $\begin{array}{l}\text { A natural or constructed wetland. The main water flow is constant and above } \\
\text { the filter bed. Plants are mainly emergent plants such as common reed (Phrag- } \\
\text { mites australis), wild rice (Zizania latifolia), and broadleaf cattail (Typha latifo- } \\
\text { lia). }\end{array}$ \\
\hline & $\begin{array}{l}\text { Surface-flow } \\
\text { biotope }\end{array}$ & $\begin{array}{l}\text { Has a biotope-like function in addition to purifying water. There is variation in } \\
\text { water depth and configuration. Example: Teganuma Biotope in Chiba Prefecture. }\end{array}$ \\
\hline & $\begin{array}{l}\text { Subsurface flow } \\
\text { (underflow) }\end{array}$ & $\begin{array}{l}\text { Constructed wetland that uses mainly emergent plants. Water flows mainly } \\
\text { through a filter bed of e.g. soil and gravel. There are horizontal (HSSF) and ver- } \\
\text { tical flow (VSSF) types. Recently, there has been growing interest in hybrid sys- } \\
\text { tems (HSSF }+ \text { VSSF) }{ }^{10} \text {. }\end{array}$ \\
\hline \multirow[t]{3}{*}{ Hydroponic } & Direct planting & $\begin{array}{l}\text { Various plants (including terrestrial plants) are planted in a treatment tank. The } \\
\text { water is shallow, and a root mat forms. The hydroponic biofilter method } \\
\text { (Tsuchiura Bio-Park in Ibaraki Prefecture) }{ }^{7} \text { falls into this category. }\end{array}$ \\
\hline & Special substrate & $\begin{array}{l}\text { Zeolite, Kanuma pumice, or other materials are put in a treatment tank to which } \\
\text { various plants (including terrestrial plants) are added. Water flows also through } \\
\text { the substrate materials. Biogeofilter methods fall into this category. }\end{array}$ \\
\hline & Float system & $\begin{array}{l}\text { Various plants (including terrestrial plants) are planted on floats in a treatment } \\
\text { tank. Roots are suspended in the water. The floating hydroponic system }{ }^{21} \text { is an } \\
\text { example. }\end{array}$ \\
\hline
\end{tabular}


water treatment than in urban areas.

National agricultural research institutes in Japan have been studying methods of purifying wastewater generated in rural areas. Here, we describe the purification methods that are currently being researched at fullscale installations and the technologies that are increasingly being deployed.

\section{FWS constructed wetland in the Koibuchi College biotope zone ${ }^{6}$}

\section{(1) Background and characteristics}

Wastewater from a dormitory at the Koibuchi College of Agriculture and Nutrition in Ibaraki Prefecture, central Japan is treated by a combined household wastewater treatment facility. $\mathrm{N}$ and $\mathrm{P}$ in the wastewater are not removed sufficiently, although organic matter is well decomposed. The effluent was being discharged into an irrigation ditch that flowed into a pond for agricultural use. Algal blooms sometimes appeared in the pond, and the major nutrient source was considered to be effluent from the dormitory. In 2004, about 0.2 ha of fallow paddy field at the college was converted into a biotope containing a 0.05 -ha surface-water-flow constructed wetland to clean the effluent from the dormitory before discharge to the pond, as well as to educate students on environmental issues. Because the zone is surrounded by rice fields and because it was to be managed as a biotope, we chose the indigenous wild rice (Zizania latifolia) for the constructed wetland vegetation because of concern that other plants (especially common reed (Phragmites australis)) might invade the rice fields and puncture their bunds. We were also concerned that any exotic species used could become weeds. The biotope was created by the staff and students themselves and is therefore useful not only for water purification, but also for the students' environmental education.

\section{(2) Full-scale operating facility}

The constructed wetland is a free-water-surface flow (FWS) type about $500 \mathrm{~m}^{2}$ in area and $0.1 \mathrm{~m}$ deep, planted with indigenous wild rice at the time of its creation. To prevent water from flowing directly to the exit, baffles were installed in the wetland to make the water flow through a circuit (Fig. 2). The wetland receives secondary treated wastewater (about 26,400 L day ${ }^{-1}$, or $52.8 \mathrm{~L} \mathrm{~m}^{-2}$ day $^{-1}$ of wetland) from a student dormitory with about 100 residents; there is therefore about $5 \mathrm{~m}^{2}$ of constructed wetland per dormitory resident. Water purified in the constructed wetland flows through the biotope area, mixes with rice field drainage, spring water, and other water, and then flows out of the

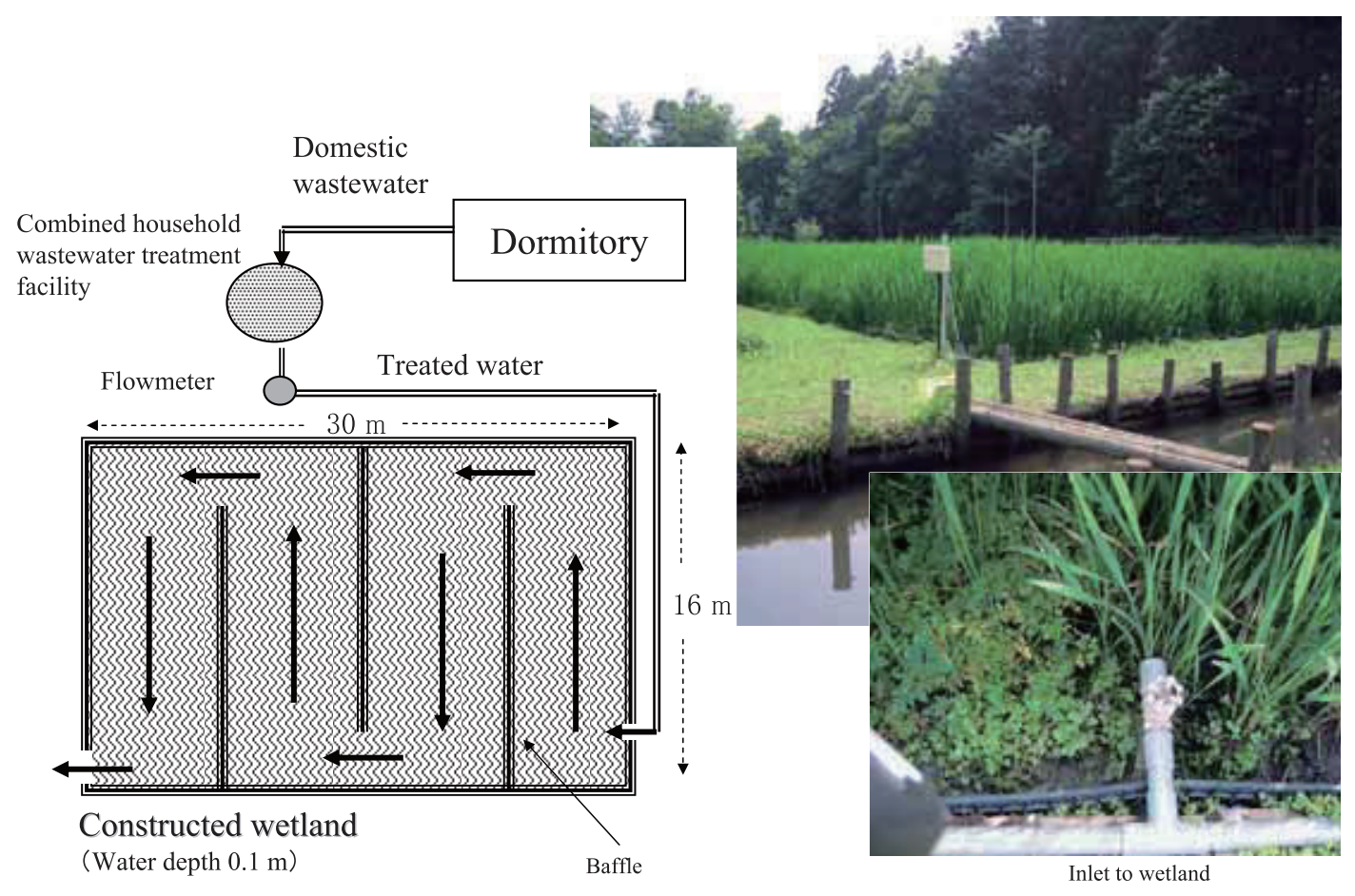

Fig. 2. Details of surface water flow constructed wetland system planted with Zizania latifolia in the biotope area 
biotope zone and into the holding pond.

\section{(3) Purification performance}

The constructed wetland has been operating since 2004. This section describes the removal of $\mathrm{N}$ and $\mathrm{P}$ during the period from April 2006 through March 2007. The annual average $\mathrm{N}$ concentration of water flowing into the constructed wetland consisted of $18.3 \mathrm{mg} \mathrm{L}^{-1}$ total $\mathrm{N}(\mathrm{TN}), 9.0 \mathrm{mg} \mathrm{L}{ }^{-1} \mathrm{NH}_{4}-\mathrm{N}$, and $7.7 \mathrm{mg} \mathrm{L}^{-1} \mathrm{NO}_{3}-$ $\mathrm{N}$, and the $\mathrm{TN}$ inflow rate (daily $\mathrm{N}$ inflow per $1 \mathrm{~m}^{2}$ of wetland) was $0.97 \mathrm{~g} \mathrm{~m}^{-2}$ day $^{-1}$. Passage through the constructed wetland reduced the TN concentration by an average of $44 \%$ (Fig. 3). The annual average $\mathrm{P}$ concentration of water entering the constructed wetland consisted of $1.86 \mathrm{mg} \mathrm{L}^{-1}$ total $\mathrm{P}(\mathrm{TP})$ and $1.31 \mathrm{mg} \mathrm{L}^{-1} \mathrm{PO}_{4}$ $\mathrm{P}$, and the TP inflow rate was $0.10 \mathrm{~g} \mathrm{~m}^{-2}$ day $^{-1}$. Passage through the constructed wetland reduced the TP concentration by $51 \%$ on average, mainly because of removal of $\mathrm{PO}_{4}-\mathrm{P}$ (which declined to a mean of $0.35 \mathrm{mg} \mathrm{L}^{-1}$ ) (Fig. 4). Analysis of the indigenous wild rice suggested that absorption by the plants accounted for $15 \%$ to $20 \%$ of annual $\mathrm{N}$ and $\mathrm{P}$ removal.

Dormitory students gained a heightened environmental awareness through observing the purification of their own wastewater in the constructed wetland, and this awareness had a positive effect on their daily lives, including a reduction in their per capita water use compared with that before wetland creation. With the passage of the 2 or 3 years since the biotope's creation,

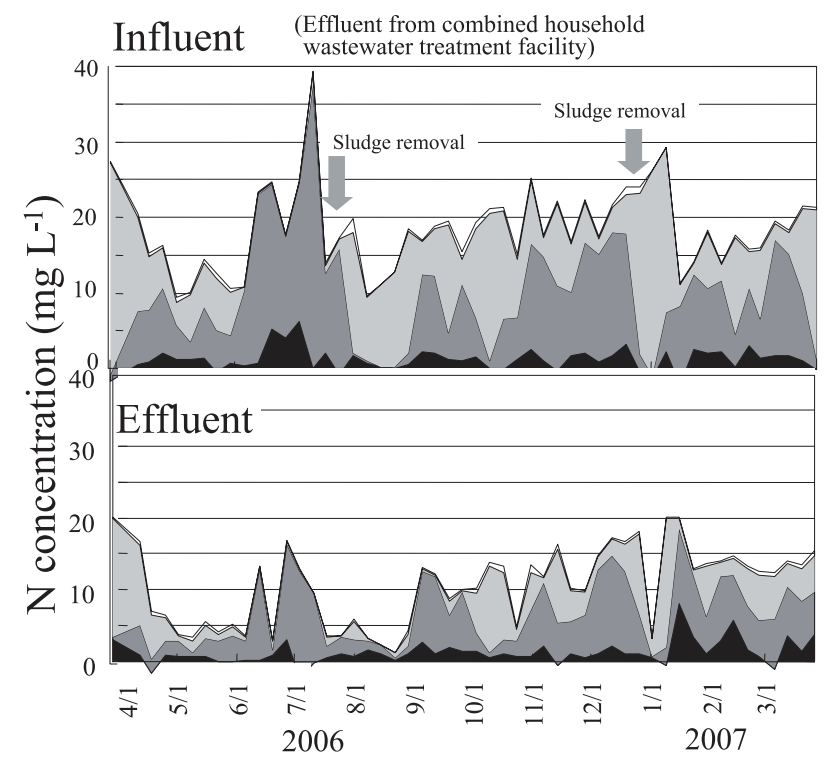

Fig. 3. Changes in nitrogen concentration in influent and effluent in the constructed wetland
$\square: \mathrm{NO}_{2}-\mathrm{N}, \square: \mathrm{NO}_{3}-\mathrm{N}, \square: \mathrm{NH}_{4}-\mathrm{N}$,
口: Org+particulate N.

many species have taken up residence there, and even endangered species have been found. The biotope forms a useful component of the college's environmental education.

\section{Hybrid-type constructed wetland for purifying milking parlor wastewater in cold regions ${ }^{12,13}$}

\section{(1) Background and characteristics}

Controls on livestock waste became more rigorous in November 2004, when the Law on Livestock Excreta Management and Recycling entered into force in Japan. However, legal regulation of dairy wastewater, such as the milking parlor wastewater (a mixture of livestock wastewater and discarded milk) generated in addition to livestock excreta, is lax. Milking parlor wastewater is not used as fertilizer because it is not as concentrated as slurry. Generally, the pollutant concentration in milking parlor wastewater is one-tenth that in livestock wastewater and ten times that in domestic wastewater. Much of this wastewater is discharged without treatment; a lowenergy, low-cost treatment method is therefore needed.

In cold regions the surface-flow type of wetland offers no purification capacity when the surface water freezes, but underflow types continue to offer purification during winter. The hybrid system is a constructed wetland that combines the VSSF type (which is aerobic and excels at nitrification) with the reducing HSSF type (which is good for denitrification). It was researched

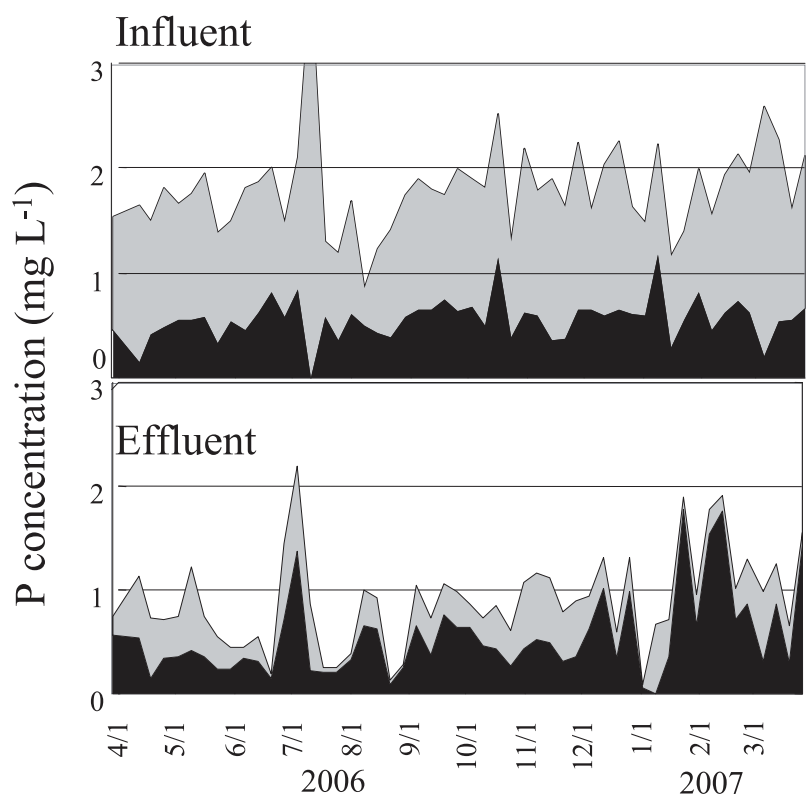

Fig. 4. Changes in phosphorus concentration in influent and effluent in the constructed wetland : $\mathrm{PO}_{4}-\mathrm{P}, \mathbf{\square}$ : Org+ particulate P. 
and developed mainly in Scandinavia as a constructed wetland system with highly efficient $\mathrm{N}$ removal, and it has been put to practical uses such as secondary treatment of gray water. The National Agricultural Research Center for Hokkaido Region teamed up with the Hokkaido Konsen Agricultural Experiment Station, Hokkaido University, TUSK Co., Ltd., and the Embetsu Town Municipal Office in Hokkaido to improve the subsurface-flow constructed wetland. They adapted it to the treatment of milking parlor wastewater and developed a purification system that could endure the bitter cold of Hokkaido.

\section{(2) Full-scale operating facility}

This purification facility services a 400-head milking parlor in the town of Betsukai, in eastern Hokkaido. It connects two VSSF wetlands (each $250 \mathrm{~m}^{2}$ ) planted with the common reed and a reducing HSSF wetland $\left(500 \mathrm{~m}^{2}\right)$, giving a total wetland area of about $1,000 \mathrm{~m}^{2}$ (Fig. 5).

The elevation difference from the wastewater entrance to the exit is about $10 \mathrm{~m}$. Wastewater is purified by gravity and other natural energy flows; no electricity or other outside energy source is used. An automatic siphon before each of the two VSSF wetlands intermittently releases temporarily stored wastewater onto their surfaces.

The VSSF wetlands treat wastewater by filtration and adsorption by pebbles, sand and other materials, decomposition of organic matter by aerobic microorganisms, and nitrification of ammonium N. The third, HSSF, wetland uses anaerobic microorganisms to denitrify nitrate to $\mathrm{N}_{2}$, which is released into the atmosphere. These wetlands are made in such a way that in summer they decompose and remove the organic matter and $\mathrm{N}$ components that in winter are accumulated by filtration and adsorption and that are not subject to the action of microorganisms owing to the low temperatures.

Phosphorus that accumulates in the system and is gradually released is reduced in amount by adsorption on calcium carbonate and other substances in a pool between the second VSSF and the HSSF. Adsorbed P can

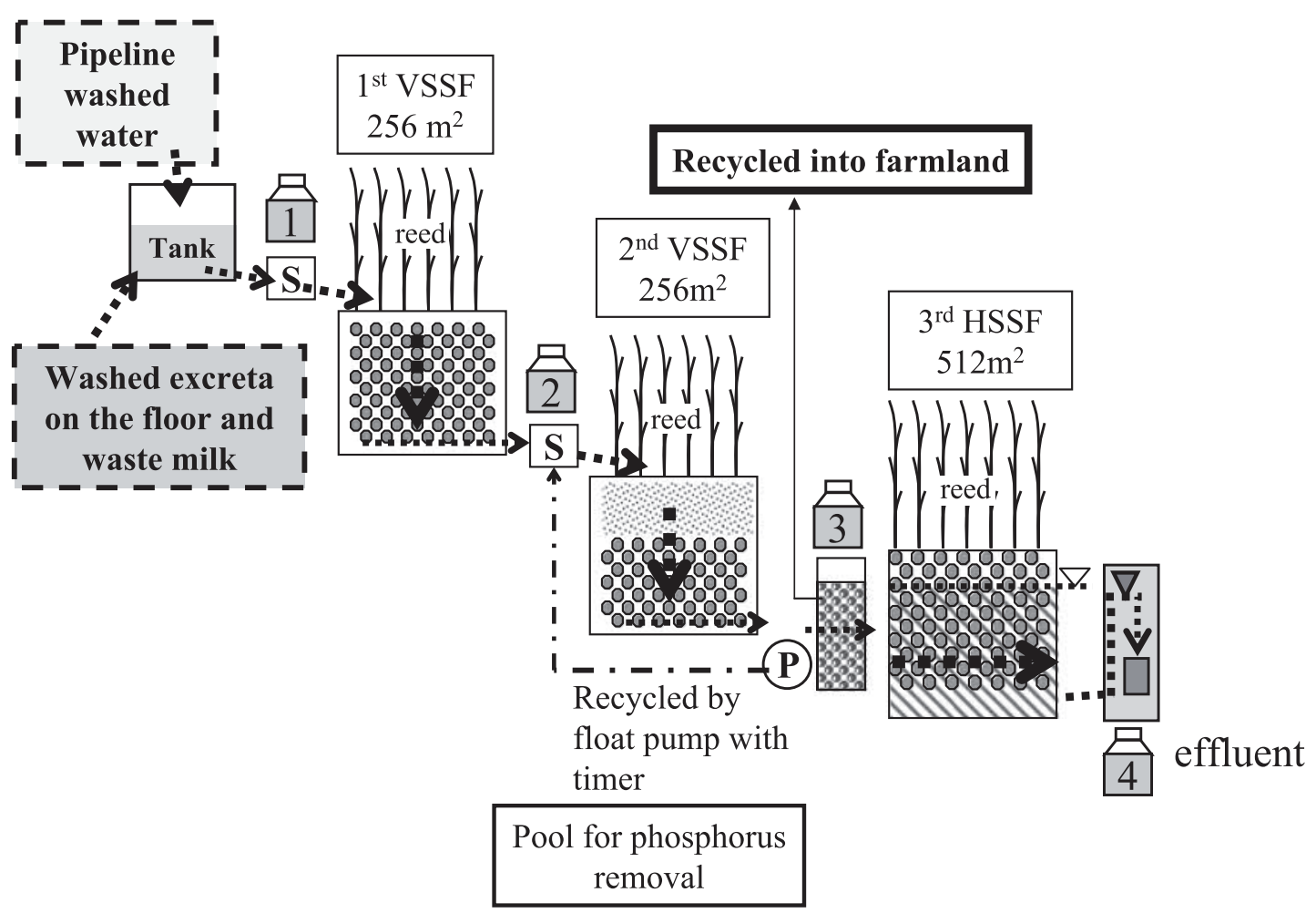

Fig. 5. Schematic diagram of the hybrid reed bed system used to treat raw dairy wastewater in eastern Hokkaido Japan, since Nov. 2005

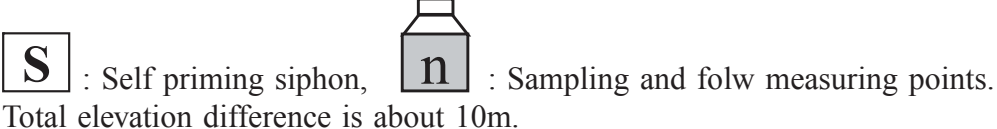


Table 2. Mean concentrations of COD, SS, TN, and TP in influents and effluents of the hybrid-type constructed wetland for purifying milking parlor wastewater

\begin{tabular}{|c|c|c|c|c|c|c|c|c|c|c|c|c|}
\hline \multirow{3}{*}{$\begin{array}{l}\text { Period } \\
\\
\text { Nov. } 2005 \text { - Apr. } 2006 \\
\text { 1st winter }\end{array}$} & \multicolumn{3}{|c|}{ COD } & \multicolumn{3}{|c|}{ SS } & \multicolumn{3}{|c|}{ Total N } & \multicolumn{3}{|c|}{ Total P } \\
\hline & \multicolumn{2}{|c|}{$\begin{array}{l}\text { In Out } \\
\left(\mathrm{mg} \mathrm{L}^{-1}\right)\end{array}$} & \multirow{2}{*}{$\begin{array}{c}\text { Decrease } \\
(\%)\end{array}$} & \multicolumn{2}{|c|}{$\begin{array}{l}\text { In Out } \\
\left(\mathrm{mg} \mathrm{L}^{-1}\right)\end{array}$} & \multirow{2}{*}{$\begin{array}{c}\text { Decrease } \\
(\%)\end{array}$} & \multicolumn{2}{|c|}{$\begin{array}{l}\text { In Out } \\
\left(\mathrm{mg} \mathrm{L}^{-1}\right)\end{array}$} & \multirow{2}{*}{$\begin{array}{c}\text { Decrease } \\
(\%)\end{array}$} & \multicolumn{2}{|c|}{$\begin{array}{l}\text { In Out } \\
\left(\mathrm{mg} \mathrm{L}^{-1}\right)\end{array}$} & \multirow{2}{*}{$\begin{array}{c}\text { Decrease } \\
(\%)\end{array}$} \\
\hline & 3,259 & 263 & & 1,499 & 34 & & 137 & 18 & & 34.5 & 3.1 & \\
\hline $\begin{array}{l}\text { May } 2006 \text { - Oct. } 2006 \\
\text { growing }\end{array}$ & 1,663 & 266 & 84 & 303 & 35 & 88 & 68 & 24 & 64 & 18.8 & 4.8 & 75 \\
\hline $\begin{array}{l}\text { Nov. } 2006 \text { - Mar. } 2007 \\
\text { 2nd winter }\end{array}$ & 1,934 & 228 & 88 & 390 & 45 & 88 & 85 & 20 & 77 & 20.4 & 5.7 & 72 \\
\hline
\end{tabular}

be returned to farmland as fertilizer (Fig. 5).

\section{(3) Purification performance}

This system started wastewater treatment in November 2005. About 17,000 L (17 $\mathrm{L} \mathrm{m}^{-2}$ of wetland) of milking parlor wastewater flows into it each day. Although the winter air temperature was below $0{ }^{\circ} \mathrm{C}$ from December through February, the water in the system was at $0.6{ }^{\circ} \mathrm{C}$ at the lowest, and it did not freeze. The team measured the purification performance for 1 year and 4 months from the start of operation; the period therefore included a winter (Table 2). Average inflow water quality showed 2,285 $\mathrm{mg} \mathrm{L}^{-1} \mathrm{COD}$ (chemical oxygen demand) (=1,673 $\mathrm{mg} \mathrm{L}^{-1} \mathrm{BOD}$ [biological oxygen demand]), $97 \mathrm{mg} \mathrm{L}^{-1} \mathrm{TN}$, and $24.8 \mathrm{mg} \mathrm{L}^{-1} \mathrm{TP}$. Inflow rates (amounts flowing in daily per $1 \mathrm{~m}^{2}$ of wetland) were $38.8 \mathrm{~g} \mathrm{~m}^{-2}$ day $^{-1} \mathrm{COD}\left(28.4 \mathrm{~g} \mathrm{~m}^{-2}\right.$ day $^{-1}$ BOD), $1.65 \mathrm{~g} \mathrm{~m}^{-2}$ day $^{-1} \mathrm{TN}$, and $0.43 \mathrm{~g} \mathrm{~m}^{-2}$ day $^{-1} \mathrm{TP}$. The system achieved purification rates of $90 \%$ to $98 \%$ for organic matter (suspended solids, coliform bacteria, BOD, etc.), and $70 \%$ to $80 \%$ for $\mathrm{N}$ and $\mathrm{P}$, thereby providing water quality that satisfies wastewater standards (120 $\mathrm{mg} \mathrm{L}^{-1} \mathrm{BOD}, 60 \mathrm{mg} \mathrm{L}^{-1} \mathrm{~N}$ and $8 \mathrm{mg} \mathrm{L}^{-1} \mathrm{P}$ ).

Similar systems for treating milking parlor wastewater have now been built in Hokkaido. Research is under way to improve them by taking into consideration local climate and topography, the characteristics of the bed materials used, and other factors. In the town of Embetsu there is an attempt under way to plant forage rice (Oryza sativa) instead of common reed in the third, HSSF wetland, use it to capture the nitrogen and phosphorus in the wastewater, and achieve a resource cycle within a single farming operation. The results are eagerly awaited.

\section{Biogeofilter channel}

\section{(1) Characteristics}

The biogeofilter (BGF) channel is a unique Japanese system developed by the former Water Quality
Conservation Laboratory of the National Agricultural Research Center ${ }^{1-5}$. The BGF channel concept uses $\mathrm{N}$ and $\mathrm{P}$ in the wastewater as fertilizer for crop production, thus adding value to the water treatment system. Its use has been explored for the purification of wastewater with various concentrations of nutrient salts, including water released from household wastewater treatment facilities, lake water and waste soilless culture solution. Research is being conducted also by prefectural agricultural experiment stations, universities and other institutions, and BGF channels have been built for residences, schools and tourism facilities.

BGF channels are filled with filter material (such as zeolite with particle sizes of 3 to $10 \mathrm{~mm}$ ), and then planted out. As wastewater flows downstream through the channel, its $\mathrm{N}$ and $\mathrm{P}$ are removed by the action of the plant roots, filter material and microorganisms. Filter material height is adjusted to suit the plants' moisture tolerance. If the top of the material is about $10 \mathrm{~cm}$ above the water level for terrestrial plants (Fig. 6) and at about water level for aquatic plants, both types of plants can be grown in the same channel. Most agricultural and flower crops grown in upland fields grow well in the channels and show good nutrient removal performance, comparable to that of aquatic plants ${ }^{1}$. Such channels can remove the $\mathrm{N}$ and $\mathrm{P}$ in wastewater while functioning as, for example, planters, flower gardens and vegetable gardens in the vicinity of residences or rural sewage treatment plants.

It is possible to enhance the purification function by careful filter material selection. For example, zeolite improves the efficiency of removal of ammonium $\mathrm{N}$ because of its high cation exchange capacity, and Kanuma pumice improves the removal efficiency of $\mathrm{P}$ because of its high $\mathrm{P}$ adsorption capacity ${ }^{17,22}$. To remove $\mathrm{N}$ from wastewater with low concentrations of organic matter (such as waste fertigation fluid), use of a lime-sulfur agent makes it possible to promote denitrification by 


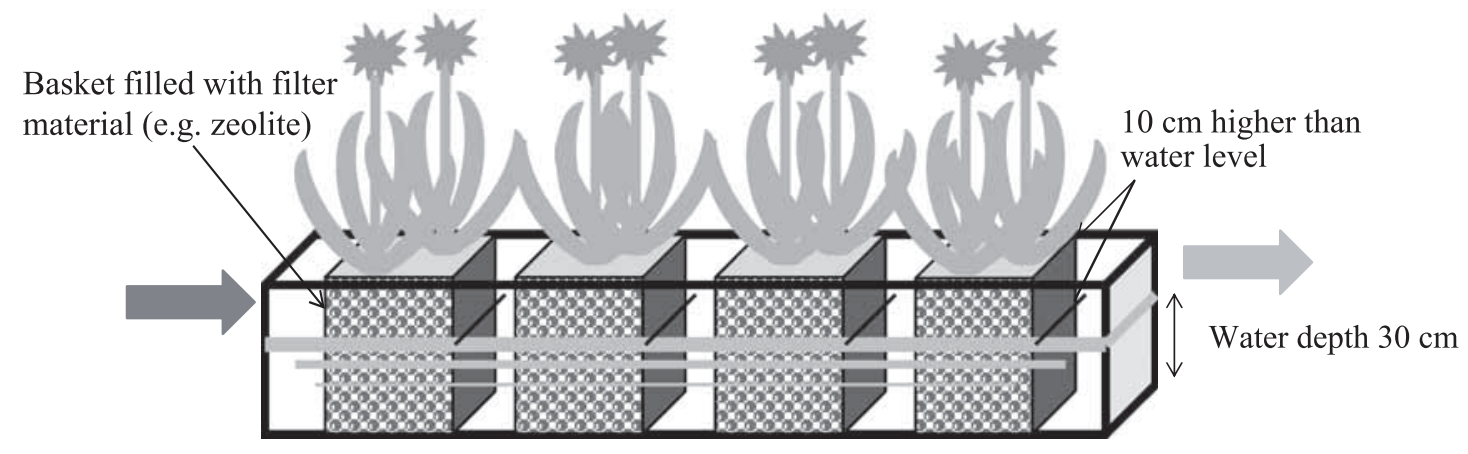

Fig. 6. Biogeofilter channel(plant-bed filter channel)

autotrophic sulfur-oxidizing bacteria.

\section{(2) Purification performance}

Absorption by plants accounts for a comparatively large part of $\mathrm{N}$ and $\mathrm{P}$ removal in the BGF ditches ${ }^{1,2,4}$. In a test of a channel using zeolite as the filter material and artificial wastewater with a high nitrate- $\mathrm{N}$ content as the $\mathrm{N}$ constituent, growing an appropriate combination of plants made it possible, except in midwinter, to achieve an $\mathrm{N}$ removal rate of $0.8 \mathrm{~g} \mathrm{~m}^{-2}$ day $^{-1}$ and a $\mathrm{P}$ removal rate of $0.15 \mathrm{~g} \mathrm{~m}^{-2}$ day $^{-1}$ per unit area of ditch ${ }^{1}$. To apply this to the treatment of secondary-treated domestic wastewater, obtaining a removal rate of about $70 \%$ (except in winter) would require a channel area of 5 to $6.5 \mathrm{~m}^{2}$ per person. This would provide treated wastewater with very low concentrations of $\mathrm{N}$ and $\mathrm{P}$. In summer, when the plants grown in the channels are flourishing, secondary effluent with an average $\mathrm{N}$ concentration of $10 \mathrm{mg} \mathrm{L}^{-1}$ can be purified down to an $\mathrm{N}$ level lower than that of rainwater ${ }^{15-17}$.

Table 3 shows examples of the results of using pilot and full-scale systems to treat various kinds of wastewater produced in rural areas. The BGF channel was effective for treating wastewater with a wide range of concentrations of nutrient salts. Use of Kanuma soil as a bed filter appeared to improve P removal.

\section{(3) Use of BGF in local municipalities}

The Akita Prefectural University Environmental and Ecological Engineering Laboratory has worked with municipalities in using BGF channels in demonstration research on the advanced treatment ( $\mathrm{N}$ and $\mathrm{P}$ removal) of treated wastewater from a combined household wastewater treatment facility and from rural sewage treatment plants.

A BGF channel built at a rural wastewater treatment plant in the city of Akita in northern Honshu was hand-made with readily bought materials such as ply-

Table 3. Results of treatment various kinds of wastewater in rural areas by using biogeofilters

\begin{tabular}{|c|c|c|c|c|c|}
\hline \multirow[t]{2}{*}{ Wastewater } & \multicolumn{2}{|c|}{ Concentration $\left(\mathrm{mg} \mathrm{L}^{-1}\right)$} & \multirow{2}{*}{$\begin{array}{l}\text { Average removal } \\
\text { rate }\left(\mathrm{g} \mathrm{m}^{-2} \text { day }^{-1}\right)\end{array}$} & \multirow{2}{*}{$\begin{array}{l}\text { Bed } \\
\text { material }\end{array}$} & \multirow[t]{2}{*}{ Plants } \\
\hline & Influent & Effluent & & & \\
\hline Eutrophic pond water ${ }^{3}$ & $\begin{array}{l}N: 3-6 \\
P: 0.1-0.2\end{array}$ & $\begin{array}{l}N: 0.3-5 \\
P: 0.02\end{array}$ & $\begin{array}{l}\text { (annual average) } \\
\mathrm{N}: 0.45 \\
\mathrm{P}: 0.02\end{array}$ & Zeolite & $\begin{array}{l}\text { Marigold, papyrus, } \\
\text { kenaf, peppermint, } \\
\text { Italian ryegrass, etc. }\end{array}$ \\
\hline $\begin{array}{l}\text { Secondary effluent } \\
\text { (domestic wastewater) }^{16}\end{array}$ & $\begin{array}{l}\mathrm{N}: 10-11 \\
\mathrm{P}: 4.5-5.3\end{array}$ & $\begin{array}{l}\mathrm{N}: 1.2-4.4 \\
\mathrm{P}: 2.5-4.4\end{array}$ & $\begin{array}{l}\text { (winter)-(summer) } \\
\mathrm{N}: 0.45-0.7 \\
\mathrm{P}: 0.1-0.18\end{array}$ & Zeolite & $\begin{array}{l}\text { Kenaf, tomato, } \\
\text { lemon grass, basil, } \\
\text { etc. }\end{array}$ \\
\hline 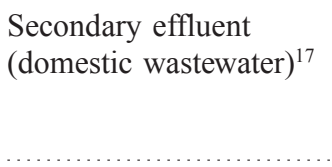 & $\begin{array}{l}\mathrm{N}: 25.9 \\
\mathrm{P}: 6.62\end{array}$ & $\begin{array}{l}\mathrm{N}: 0.31 \\
\mathrm{P}: 0.22\end{array}$ & $\begin{array}{l}\text { (summer: June to } \\
\text { September) } \\
\mathrm{N}: 1.34 \\
\mathrm{P}: 0.34\end{array}$ & $\begin{array}{l}\text { Zeolite and } \\
\text { Kanuma } \\
\text { pumice }\end{array}$ & $\begin{array}{l}\text { Papyrus, rice, } \\
\text { arrowhead, Chinese } \\
\text { water spinach }\end{array}$ \\
\hline $\begin{array}{l}\text { Discharged } \\
\text { soilless culture } \\
\text { solution }^{4}\end{array}$ & $\begin{array}{l}N: 100-200 \\
P: 5-15\end{array}$ & $\begin{array}{l}N: 30-130 \\
P: 0-7\end{array}$ & $\begin{array}{l}\text { (summer: June to } \\
\text { September) } \\
\mathrm{N}: 0.9-1.5 \\
\mathrm{P}: 0.08-0.15\end{array}$ & Zeolite & $\begin{array}{l}\text { Sorghum, Chinese } \\
\text { water spinach, } \\
\text { portulaca }\end{array}$ \\
\hline
\end{tabular}


wood and waterproof tarpaulins. The use of materials such as lapilli and the planting of forage rice are being considered. The channel is also used for environmental education, such as for growing papyrus, which has a purification function and can be used as a raw material in teaching local elementary school students how to make paper.

At a nursing home in the former town of Futatsui (now part of the city of Noshiro), a channel was built with mainly thinned Japanese cedar trees and Futatsuiproduced zeolite, thereby making maximum use of local resources. It is used for the advanced treatment of secondary effluent. Because the BGF ditch is planted with agricultural crops and flowers it requires cultivation management, such as seasonal replanting, in order to sustain its purification function. Ten to twenty members of the town women's association perform this task once or twice a week. Such BGF ditches that use local resources can have multiple purposes, including environmental education, horticultural therapy, and providing the elderly with a sense of purpose (Photo 1).

\section{General discussion and conclusions}

We describe three vegetation-based wastewater treatment techniques that have been studied at the full scale or have been put to practical use in rural areas. The characteristics of these three systems, their purification performance and management requirements are summarized as follows (Table 4):

1) The FWS constructed wetland planted with indigenous wild rice in the biotope area of Koibuchi College had lower nutrient removal efficiency than the other two systems. This means that it required a larger area. However, because of its simple structure it had the advantage that staff and students could create it from a paddy field by themselves. The biotope area including this wetland has helped in the students' environmental education. Some management of plants, harvesting of wetland vegetation, and weeding around the wetland are needed.
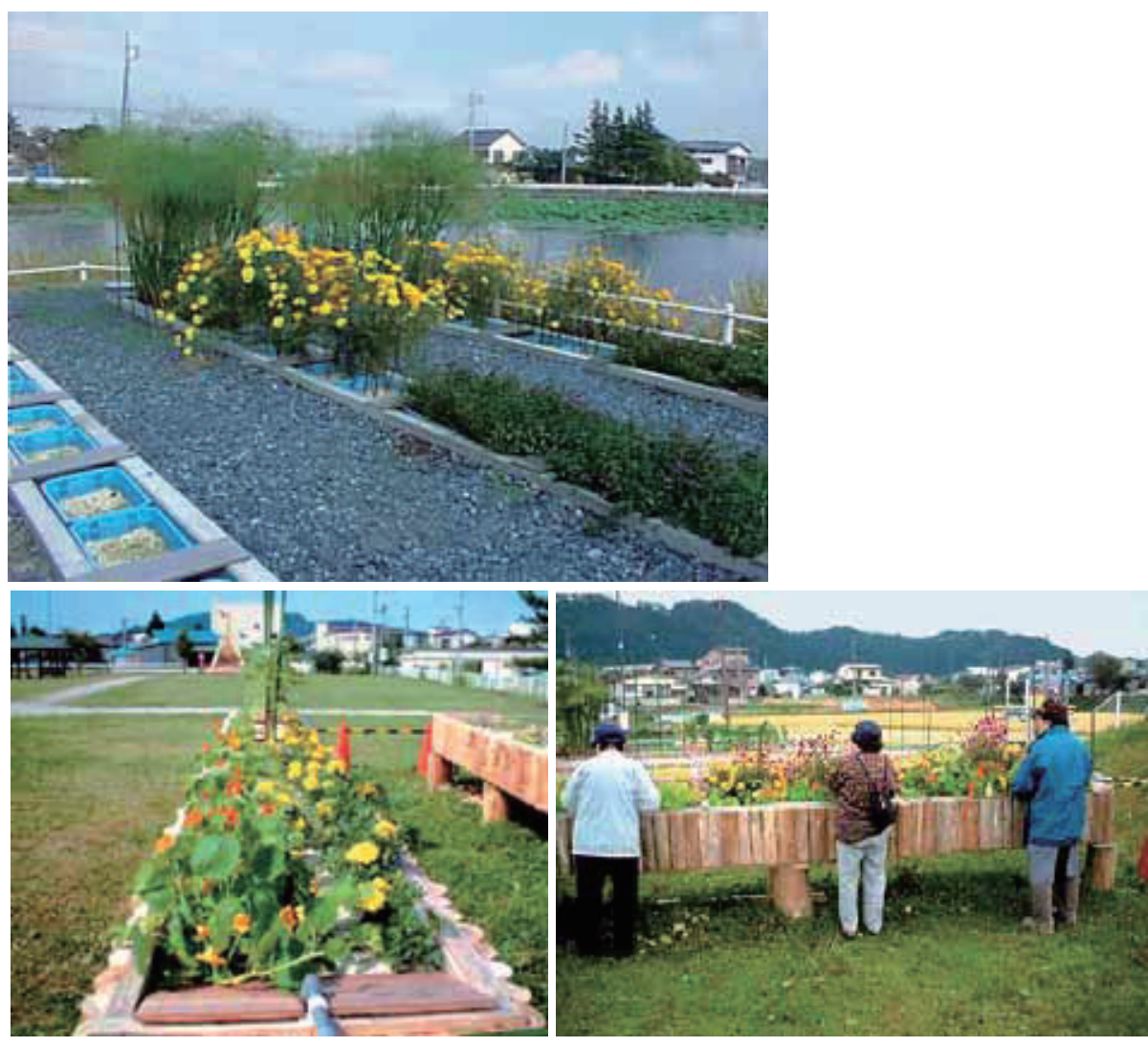

Photo 1. Garden-type BGF channel

Top: BGF channels for treatment of eutrophic pond water (Tsukuba City in Ibaraki Prefecture). Left: BGF channels at a nursing home in the former town of Futatsui (now part of Noshiro City in Akita Prefecture).

Right: Members of the town women's association maintaining plants grown in a channel. 
Table 4. Comparison of three vegetation-based wastewater treatment facilities

\begin{tabular}{|c|c|c|c|c|}
\hline & Construction & $\begin{array}{l}\text { Purification } \\
\text { performance (year-round) }\end{array}$ & $\begin{array}{l}\text { Vegetation and } \\
\text { management }\end{array}$ & Added value \\
\hline $\begin{array}{l}\text { Surface-water- } \\
\text { flow constructed } \\
\text { wetland in biotope } \\
\text { area of Koibuchi } \\
\text { College }\end{array}$ & $\begin{array}{l}\text { Created by staff } \\
\text { and students }\end{array}$ & $\begin{array}{l}\mathrm{N} \text { removal rate: } 0.37 \mathrm{~g} \\
\mathrm{~m}^{-2} \text { day }^{-1} \\
\mathrm{P} \text { removal rate: } 0.050 \mathrm{~g} \mathrm{~m}^{-2} \text { day }^{-1} \\
\text { No purification } \\
\text { capacity in cold } \\
\text { regions when water } \\
\text { freezes }\end{array}$ & $\begin{array}{l}\text { Indigenous wild rice } \\
\text { Harvest once or } \\
\text { twice every year; } \\
\text { weed around the } \\
\text { wetland }\end{array}$ & $\begin{array}{l}\text { Useful for } \\
\text { students' } \\
\text { environmental } \\
\text { education }\end{array}$ \\
\hline $\begin{array}{l}\text { Hybrid wetland for } \\
\text { purifying milking } \\
\text { parlor wastewater } \\
\text { in cold regions }\end{array}$ & $\begin{array}{l}\text { Professionally } \\
\text { constructed }\end{array}$ & $\begin{array}{l}\mathrm{N} \text { removal rate: } 1.3 \mathrm{~g} \\
\mathrm{~m}^{-2} \text { day }^{-1} \\
\mathrm{P} \text { removal rate: } 0.3 \mathrm{~g} \\
\mathrm{~m}^{-2} \text { day }^{-1} \\
\text { Withstood the bitter } \\
\text { cold of Hokkaido }\end{array}$ & $\begin{array}{l}\text { Common reed } \\
\text { No harvesting of } \\
\text { reeds }\end{array}$ & $\begin{array}{l}\text { Forage rice is to } \\
\text { be produced in } \\
\text { part of the wetland }\end{array}$ \\
\hline $\begin{array}{l}\text { Biogeofilter } \\
\text { channel }\end{array}$ & $\begin{array}{l}\text { Small-scale } \\
\text { facilities created } \\
\text { by locals; large- } \\
\text { scale facilities } \\
\text { constructed by } \\
\text { professionals }\end{array}$ & $\begin{array}{l}\mathrm{N} \text { removal rate: } \sim 0.8 \mathrm{~g} \\
\mathrm{~m}^{-2} \text { day }^{-1} \\
\mathrm{P} \text { removal rate: } \sim 0.15 \\
\mathrm{~g} \mathrm{~m}^{-2} \text { day }^{-1}\end{array}$ & $\begin{array}{l}\text { Various kinds of } \\
\text { crops and flower } \\
\text { crops. Requires } \\
\text { cultivation } \\
\text { management, } \\
\text { (seasonal replanting, } \\
\text { harvesting) }\end{array}$ & $\begin{array}{l}\text { Functioning as } \\
\text { planters for flower } \\
\text { gardens and } \\
\text { vegetable gardens } \\
\text { for residences, } \\
\text { schools, and } \\
\text { tourism facilities }\end{array}$ \\
\hline
\end{tabular}

2) The hybrid constructed wetland for purifying milking parlor wastewater showed high $\mathrm{N}$ and $\mathrm{P}$ removal efficiency and provided water of a quality that satisfied wastewater standards yearround. It was able to withstand the bitterly cold climate. The reeds are not usually harvested because their dead foliage insulates the wetland in winter. Its disadvantage is that this wetland must be built by professionals.

3) The $\mathrm{N}$ and $\mathrm{P}$ removal efficiency of the biogeofilter was relatively high. Its outstanding characteristic is that it acts as a planter, sustaining flower and vegetable gardens. Therefore, it requires volunteers for cultivation management such as seasonal replanting, harvesting and treatment of crop residues.

Treatment facilities should therefore be selected to suit the purpose and limitations of each site in consideration of the advantages and drawbacks of each technique. There are likely to be many sites suitable for the introduction of these systems in rural areas.

Vegetation-based wastewater treatment methods require some degree of vegetation management. The need for vegetation management work sometimes becomes a barrier to the introduction of these treatment methods if the area has no volunteers or staff for vegetation management. This is especially true of BGF. It is important that such facilities be improved and developed to make it easy and enjoyable to maintain the vegetation. This will help to encourage the increased adoption of vegetation-based wastewater treatment.

We think that if these methods are to be popularized and operated for a long time, then residents require an understanding of nutrient recycling and the improvement of aquatic ecosystems. Recently, residents have organized many activities to improve aquatic ecosystems near their homes. In these areas, we think that residents will be likely to volunteer to manage the vegetation in the wastewater treatment facilities because they understand the importance of nutrient recycling and the improvement of aquatic ecosystems.

Finally, we examined a traditional vegetation-based purification system once used by farmers in the Kyushu region. According to Shiramasa (1977), until about the 1960s, people on the Shiroishi Plain in Kyushu's creek district did not run kitchen wastewater, bathwater and other gray water directly into the creeks, and the creek water quality was well maintained ${ }^{20}$. Behind the farmhouses there were gray water holding ponds called $y u$ done, which emptied into small lotus or similar ponds (Fig. 7). According to Shiramasa, in the typical system, "Wastewater from the kitchen sink and the bath were directed into a shallow pond about $15 \mathrm{~cm}$ deep, in the bottom of which was a mud layer of about $50 \mathrm{~cm}$. Lo- 


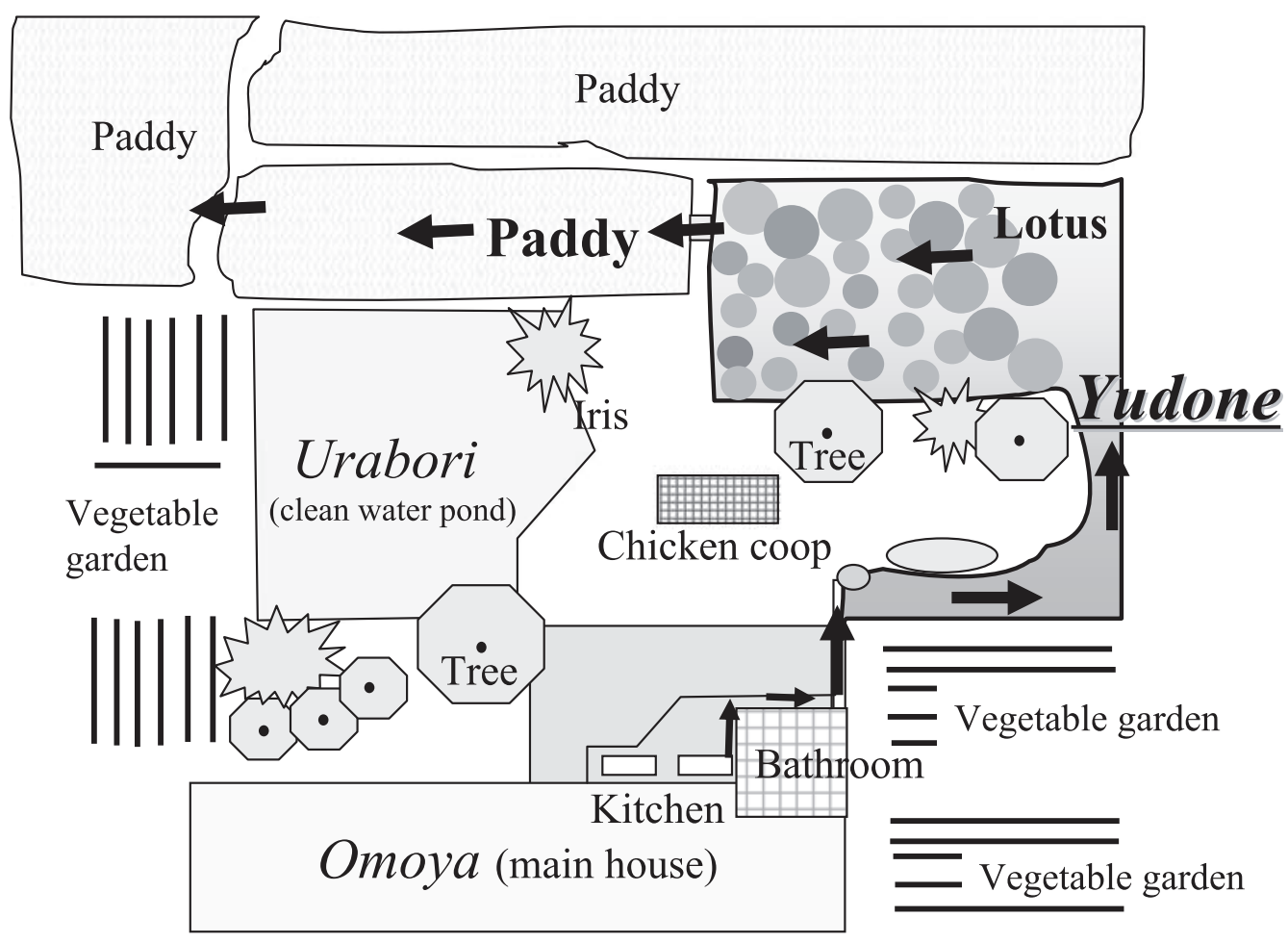

Fig. 7. Yudone, a traditional vegetation-based purification system once used by Kyushu-region farmers (drawn from a description given in Juи no Shisou, by Gouji Shiramasa)

$\longrightarrow$ : Water flow.

tus were planted in the downstream portion, which led into a small rice paddy ... In the process of slowly flowing through the yudone, the graywater would be purified". This system reduced $\mathrm{N}$ levels to about $50 \%$ of those in the wastewater emanating from the kitchen and bathroom $^{14}$.

It is believed that the purpose of the yudone in this region, where water was scarce and precious, was to make effective use of the fertilizing component of graywater instead of wasting $i t^{20}$; one could say that, in effect, it was the concept of mottainai-not wasting anything-that protected the quality of the creek water. It is very interesting that the use of vegetation-based purification systems such as the yudone was passed down through the generations as a tradition in rural Japan long before the study of constructed wetlands began in the West. In the course of modernization, the yudone were filled in and no longer exist, but it is perhaps necessary for future research to reassess the culture passed on to us by previous generations and to reconstruct it in ways suited to the present.

In conclusion:

1) We recommend the constructed wetland system and the BGF channel mentioned in this paper as promising wastewater treatment options suitable to rural areas.

2) Introduction of these vegetation based wastewater treatment methods enables us to remove nitrogen and phosphorus in the wastewater arising from everyday living and agricultural production in rural areas, such as domestic wastewater, milking parlor wastewater and soilless culture system discharges.

3) These wastewater treatment methods should be popularized in rural areas under the appropriate environmental policy in order to improve the water environment in rural areas.

\section{Acknowledgments}

We are grateful to Dr. Shinichi Ono (National Institute for Agro-Environmental Sciences) for encouraging us to write this review.

\section{References}

1. Abe, K. \& Ozaki, Y. (1998) Comparison of useful ter- 
restrial and aquatic plant species for removal of nitrogen and phosphorus from domestic wastewater. Soil Sci. Plant Nutr., 44, 599-607.

2. Abe, K. \& Ozaki, Y. (1999) Evaluation of useful plants for the treatment of polluted pond water with low $\mathrm{N}$ and P concentrations. Soil Sci. Plant Nutr., 45, 409417.

3. Abe, K. \& Ozaki, Y. (2001) Treatment of eutrophic pond water by using plant bed filter ditches of garden type throughout the year and effect of burying organic matter within the beds in the midstream. Soil Sci. Plant Nutr., 47, 55-66.

4. Abe, K. et al. (2005) Treatment of discharged solution from the rose soilless culture system by using plant bed filter ditches. Jpn. J. Soil Sci. Plant Nutr., 37(4), 16-22 [In Japanese with English summary].

5. Abe, K. \& Ozaki, Y. (2007) Wastewater treatment by using kenaf in paddy soil and effect of dissolved oxygen concentration on efficiency. Ecol. Eng., 29, 125132.

6. Abe, K., Komada, M. \& Ookuma, A. (2008) Efficiency of removal of nitrogen, phosphorus, and zinc from domestic wastewater by a constructed wetland system in rural areas: a case study. Water Sci. Technol., 58, 2427 $-2433$.

7. Aizaki, M. \& Nakazato, H. (1997) Development of constructed wetland using hydroponic biofilter method for purification of hyper-eutrophic lake water. $J . J p n$. Soc. Water Environ., 20, 622-628.

8. Brix, H. (1993) Wastewater treatment in constructed wetlands: system design, removal process, and treatment performance. In Constructed wetlands for water quality improvement, ed. Moshiri, G. A., CRC Press, Boca Raton, Florida.

9. Brix, H., Schierup, H. H. \& Aris, C. A. (2007) Twenty years experience with constructed wetland systems in Denmark - what did we learn? Water Sci. Technol., 56, 63-68.

10. Cooper, P (1999) A review of design and performance of vertical flow and hybrid reed bed treatment systems. Water Sci. Technol., 40(3), 1-9.

11. Hosomi, M. (2000) Conservation and utilization of wetland ecosystems (Chapter 8). In Eco-technology for environmental remediation, ed. Sudo, R., Koudannsya, Tokyo, Japan, 167-190 [In Japanese].

12. Kato, K. et al. (2006) Early performance of hybrid reed bed system to treat milking parlour wastewater in cold climate in Japan. In 10th International Conference on Wetland Systems for Water Pollution Control, Lis- bon, Portugal, International Water Association, 11111118.

13. Kato, K. et al. (2007) First year performance of a realscale hybrid wetland system for the treatment of dairy wastewater in a cold climate in Japan. In 2nd International Symposium on Wetland Pollutant Dynamics and Control (WETPOL 2007), Extended abstracts, Volume I, Tartu, Estonia, 150-152.

14. Ogushi, K., Yuge, K. \& Nakano, Y. (2006) Evaluation of nitrogen circulation of a creek in Shiroishi area, Japan: nitrogen circulation model. Sci. Bull. Fac. Agric., Kyushu University, 61(2), 311-323 [In Japanese with English summary].

15. Ozaki, Y. \& Abe, K. (1995) Present problem and view for resources - recycling wastewater treatment using various plants - in order to construct a beautiful landscape. Yousui to haisui (Journal of Water and Waste), 35(9), 5-7 [In Japanese].

16. Ozaki, Y. (1997) Development of resource-recycling system for domestic wastewater treatment by using farm crops. Japanese Journal of Water Treatment Biology, 33(3), 97-106 [In Japanese].

17. Ozaki, Y. (2001) Resource-recycling system for domestic wastewater treatment using biogeofilter ditches planted with useful plants. JARQ, 33, 243-249.

18. Reed, S. C., Crites, R. W. \& Middlebrooks, E. J. (1995) National systems for waste management and treatment. McGraw-Hill Inc., New York.

19. River and Watershed Research Institute (2002) Technical information for design of vegetation based water treatment facilities. Miscellaneous Publication No. 5 of River and Watershed Research Institute, Tokyo [In Japanese].

20. Shiramasa, G. (1977) Ninngenn Shennshyo 8 Juи no Shisou. Rural Culture Association, Tokyo, Japan, pp. 211.

21. Takagaki, M., Maruo, T. \& Shinohara, Y. (2004) Development of vegetable production system by purification of eutrophic Tega-lake water. Acta Hort., 644, 85-90.

22. Takasuna, H., Ozaki, Y. \& Abe, K. (2005) Water purification of plant bed filter materials using kanumatsuchi. Jpn. J. Water Treat. Biol., 41, 51-59 [In Japanese with English summary].

23. Vymazal, J. (2007) Removal of nutrients in various types of constructed wetlands. Sci. Total Environ., 380, $48-65$.

24. Vymazal, J. (2009) The use constructed wetlands with horizontal sub-surface flow for various types of wastewater. Ecol. Eng., 35, 1-17. 